\title{
Wave hazards on microtidal shore platforms: Testing the relationship between morphology and exposure.
}

David M. Kennedy ${ }^{1 *}$, Daniel Ierodiaconou ${ }^{2}$, Adam Weir $^{3}$, and Barbara Brighton ${ }^{4}$

${ }^{1}$ School of Geography, The University of Melbourne, Parkville, Vic 3010, Australia

${ }^{2}$ School of Life and Environmental Sciences, Deakin University, Warrnambool, Vic, Australia

${ }^{3}$ Surf Life Saving New South Wales, Belrose, NSW, Australia

${ }^{4}$ Surf Life Saving Australia, Rosebery, NSW, Australia

*Corresponding Author: Email: davidmk@unimelb.edu.au, Ph: +61383449168, Fax: $+61393494218$

\begin{abstract}
Open-ocean rocky coasts are dangerous environments when there is a coincidence of recreational activities occurring in areas of high wave energy. Management of drowning fatalities and near-drowning incidents on these landforms is difficult as traditional approaches to beach safety cannot be easily transferred to rocky shores. In this study we take a morphological approach to quantifying the relative danger of shore platforms in microtidal regions. Platform elevation and nearshore water depth are key variables in determining the likelihood of wave overtopping of the platform edge. The relationship between these variables is tested along a $70 \mathrm{~km}$ long section of the Otway Ranges coast in Victoria, Australia. It is found that exposure is highly variable along short (100 m scale) sections of shore platforms. This variability is driven by the complexity of the nearshore morphology which can have metre-scale relief. As exposed platforms may occur in areas of low wave energy the morphological exposure index is combined with nearshore wave energy to produce a risk rating. Risk, like exposure, was found to be highly spatially variable. The relationship between elevation and water depth has the potential to provide managers with a tool for assessing safety on rocky shores.
\end{abstract}

Keywords Shore platform, hazard, waves, rock fishing, water safety, rock coast, drowning 


\section{Introduction}

Open-ocean rocky coasts are exposed environments commonly subjected to high wave energy. They are often composed of cliffs which often have ledges, termed shore platforms, developed at their base at around mean sea level elevation. The shape of the rocky coast is the result of the relative balance between processes of erosion and the rock strength of the cliffs (Stephenson et al. 2013; Sunamura 1992; Trenhaile 1987). While the precise balance between the processes that form shore platforms remains a subject of active research, waves are recognised as a major erosive agent (Kennedy et al. 2011; Stephenson et al. 2013). As waves approach the shore they interact with the seafloor; however, it is the seaward edge of the platform that is the principal site of energy dissipation in microtidal settings (Beetham and Kench 2011; Ogawa et al. 2015).

Shore platforms are also the focus of many recreational activities from walking and general sightseeing to fishing. The juxtaposition of recreational activities in a high-energy erosive environment results in a high level of risk for people. For example, in Australia 19\% of coastal fatalities occur on rocky coasts primarily when individuals fall into the sea off microtidal semi-horizontal shore platforms (SLSA 2014a; SLSA 2014b). Danger for people is greatest when they stand on the edge of a platform as this is the location where most of the energy is concentrated through processes of wave breaking.

Managing this hazard poses many challenges. Traditional approaches to water safety (e.g. volunteer lifesavers and salaried lifeguards) cannot be easily applied to rocky shores due to prohibitive costs and remoteness of locations. For beaches, safety has been improved through the development of hazard ratings based on geomorphology and consideration of breaking wave height and period (e.g. Short et al. 1993). This has been successfully used on sandy shores (Short and Hogan 1994), but has yet to be translated to rocky coasts.

It has been suggested that platform elevation and the water depth immediately seaward of the platform edge are important for quantifying the degree of danger to people recreating on these landforms (Kennedy et al. 2012; 2013). Platforms which are lower in elevation are more likely to be washed by waves, whilst deep water offshore allows wind waves to break directly on the platform edge with little dissipation of their energy. In this study we aim to 
establish the relationship between these morphological variables. We acknowledge that waves are a critical element to calculating hazard; however, the morphological approach undertaken is deliberate as topographic data is much more commonly available to managers than shallow-water wave height at the platform edge. This study explores several methods for calculating hazard in order to determine which produces the most robust index for assessing danger to people recreating on shore platforms.

\section{Regional Setting}

The southeastern facing section of the Otway Ranges, Victoria, Australia, from Grass Creek to Cape Otway (Fig. 1) is used as a study site due to its uniform geology of late Jurassic to lower Cretaceous sandstones (Douglas and Ferguson 1976; Duddy 2003). This coast is microtidal with a spring tidal range of $1.6 \mathrm{~m}$ (PoM 2013). The mean significant wave height for the Victorian coast is $2.4 \mathrm{~m}$ with a period of $8.4 \mathrm{sec}$ (Hughes and Heap 2010) and modelling indicates that the mean annual deep-water wave height in the study area is $1.4 \mathrm{~m}$ (WaterTech 2004). Mean annual minimum and maximum air temperatures for Lorne, in the center of the study area, are 11.0 and $18.9{ }^{\circ} \mathrm{C}$ respectively, with a mean annual rainfall of 827 mm (BoM 2015).

The shore platforms range up to several hundred metres in width, although most commonly they are $<80 \mathrm{~m}$ wide, extending seaward from either a vertical cliff or the base of a beach or talus slope. A semi-horizontal section at least several metres wide occurs in the mid section of the platforms most commonly within the intertidal zone. Ramparts, between $0.5-1.0 \mathrm{~m}$ high, are often found on the seaward edge of the horizontal surface (Gill 1973; Jutson 1949; 1953; Kennedy and Milkins 2015). Three distinct morphologies are found below sea level: a steeply dipping cliff, a ramp, and a subtidal reef/terrace (Kennedy 2016).

\section{Methods}

Airborne Light Detection and Radar (LiDAR) data were collected in 2007 by the Department of Environment and Primary Industries of the Victorian State Government. The surveying was conducted using a LADS Mk II system coupled with a GEC-Marconi FIN3110 inertial motion sensing system and a dual frequency kinematic global positioning system (kGPS). This dataset was processed to produce a seamless terrestrial-marine mosaic from elevations 
of $+10 \mathrm{~m}$ to depths of $-25 \mathrm{~m}$ with a final raster grid of $2.5 \mathrm{~m}$ resolution (Quadros and Rigby 2010).

Within ArcMap, profiles were drawn at c. $100 \mathrm{~m}$ intervals along the rocky shoreline. In some instances suspended sediment within the surf zone prevented the seafloor from being surveyed, however the low turbidity of the region meant that such data gaps were rare and analysis could be conducted on nearly all platforms along the $70 \mathrm{~km}$ length of coast. The profiles were manually interrogated in order to extract the platform elevation and front depth. Only sections of rocky coast which are accessible to people were analysed. Hence platforms below mean low water spring (MLWS) elevation were excluded as they would be constantly inundated. In addition locations were excluded where an intertidal reef is immediately offshore of the platform as people would have to wade or swim across a channel to access the reef at any tidal stage.

In this analysis there are two key assumptions: (1) it is low tide, and (2) exposure is calculated as the position closest to the sea where a person could stand. Low tide was chosen as this is when a platform is at its widest. It should be noted that the complex intertidal and subtidal morphology of platforms will cause waves to impact differently as tidal elevation increase; however, in this first investigation of exposure low tide was deemed to be sufficient for the analysis. The seaward edge of the platform is logically the location of greatest risk as it is closest to where waves are breaking and risk would lessen as a person moves in a landward direction. The elevation of the platform $\left(\mathrm{SP}_{\mathrm{e}}\right)$ is taken as the point closest to MLWS level where the slope was $<1^{\circ}$ over a distance of $5 \mathrm{~m}$ (Fig. 2). Front depth (FD) is calculated in three different positions depending on the type of subtidal morphology that is present, namely: (i) the base of seaward cliff, (ii) the top of subtidal terrace edge or (iii) the first break in slope on a ramp below MLWS elevation (Fig. 2).

A global wave hindcast model was downscaled to a regional scale based on year 2000 wave hindcast values (Victorian coastline) using a MIKE 21 spectral wave (SW) model developed by Water Technology using the DHI MIKE software suite (DHI 2012). Bathymetry for hindcasting was generated from a LIDAR / Multibeam mosaic (Rattray et al. 2015) and boundary depths derived from the Geoscience Australia 2009 bathymetry and topography grid $\left(0.025^{\circ}\right)$ (Whiteway 2009). The model domain incorporated the western and eastern coastlines of Victoria, Tasmania and adjacent areas of continental shelf including Bass Strait. 


\section{Results}

Platform elevation and front depth

A total of 325 individual profiles were assessed, with their elevation ranging from 0.07 to $3.14 \mathrm{~m}$ above MLWS, with an average of $0.78+/-0.51 \mathrm{~m}$. The majority $(63 \%)$ of platforms are found within the intertidal zone with a median elevation $\left(\mathrm{SP}_{\mathrm{e}}\right)$ of $0.66 \mathrm{~m}$ above MLWS (Fig. 3a). The front depth (FD) on the other hand ranges between -0.80 and $7.44 \mathrm{~m}(1.88+/-$ $1.26 \mathrm{~m}$ ), with negative values indicating a FD above MLWS elevation. The median FD is $1.75 \mathrm{~m}$ with $94 \%$ being $<4.0 \mathrm{~m}$ (Fig 3b). There is an almost random relationship between elevation and front depth $\left(r^{2}=0.004\right)$, highlighting the spatially variable nature of platform morphology (Fig. 3c).

\section{Morphological Exposure}

Exposure is defined as the likelihood of a wave overtopping the platform. As platform elevation and front depth are independent variables both are required in its calculation. It has been proposed by Kennedy et al. (2013), based on testing of 50 land-based profiles in Australia and New Zealand, that exposure be represented by equation 1:

$$
\text { Exposure }=\text { FD } x \text { Elevation }
$$

Using this relationship along the Otway Ranges coast (Fig. 4a) exposure varies from -0.82 to 10.64, with a negative value representing a platform where the front depth is located above MLWS elevation. The entire dataset trends towards zero as the platform approaches MLWS elevation regardless of the FD. Such a relationship is problematic as a platform close to MLWS with a high FD will be more exposed to waves than a higher platform with the same FD. An alternative method for calculating exposure is therefore required.

The relationship between morphological variables may therefore be better represented by equation 2:

$$
\text { Exposure }=\text { FD } / \text { Elevation }
$$


The calculated exposure values in this instance are exponential with exposure increasing greatly as the platform approaches MLWS elevation (Fig. 4b). There is a high amount of variability in exposure values for platforms of the same elevation highlighting the variance in front depth between sites. Platforms with the highest exposure tend to be lower in elevation and have a greater front depth so incoming waves break on the edge with minimal dissipation, which corresponds with field observations. The advantage of this relationship is the data no longer trends to zero based on the elevation where the platforms are normalised to, in this study MLWS. There is however, a trend towards infinity for the lowest platforms. This means that as the platform approaches MLWS elevation a decimetre variation in height will lead to a large variance in exposure. This is impractical in the field as wave transformation at the platform edge is unlikely to vary by orders of magnitude simply because of a centimetre-scale variation in height. Removing the logarithmic trend will reduce the sensitivity of the exposure calculations to values approaching zero (equation 3 ).

$$
\text { Exposure }=\log _{10}(\mathrm{FD} / \text { Elevation })
$$

A log-based transformation of the exposure values from equation [2] removes the exponential trend and the associated issues related to platforms which are close to MLWS elevation (Fig. 4c). The log-based analysis however cannot calculate negative values such as when the front of the platform is in the intertidal zone. In the field this does not appear to be an issue; in such circumstances waves are already breaking on the sea bed prior to reaching the platform edge and a person would be effectively standing in the surf zone. Exposure values calculated from equation 3 range from -2 to 1.28 with platforms of lower elevation tending to be of higher exposure, although the relationship is weak $\left(r^{2}=0.26\right)$. Exposure values also tend to decrease with decreasing FD, although like the relationship with elevation, there is a wide scatter of values (Fig. 4d). The morphological exposure relationship as represented by equation 3 therefore appears to most realistically represent exposure based on as visual field observations, although this was not tested with direct measurement of wave energy.

\section{Spatial Distribution of Exposure}

The spatial distribution of exposure, based on equation 3, is highly variable along the Otway coast. Areas of high and low exposure occur both on linear sections of shoreline as well as on 
headlands. It is common for kilometre-scale sections of coast to have similar values, but in many instances areas of high and low exposure occur within $100 \mathrm{~m}$ of each other. To highlight the site-specific nature of the exposure, two areas are used as examples: (1) Lorne (Point Grey) to Grass Creek and Marengo (Apollo Bay) to Cape Otway. These two areas lie at the northern and southern end of the study area. A fully viewable version of all the exposure values is available as an electronic GoogleEarth file in the electronic supplementary material.

Exposure values were divided into 7-categories similar to the methodology for assessing beach hazards (Short and Hogan 1994). Each class is defined on the basis of the Jenks Natural Breaks algorithm in ArcMap which subdivides the dataset based on natural breaks within the data to maximise the difference between classes. The northern section of the Lorne area has a moderate level of exposure with the majority of platforms being between 4 and 5 (Fig. 5). One platform within this area has a low exposure (category 1) with a value of -1.08 and occurs near a sandy beach. The platform $190 \mathrm{~m}$ further north however has a ranking of 4 $\left(\mathrm{M}_{\mathrm{e}}=0.26\right)$, while the next platform a further $100 \mathrm{~m}$ away has a $\mathrm{M}_{\mathrm{e}}$ of 0.78 (category 6). It is common for adjacent platforms to have different exposure ranking despite their close proximity (around $100 \mathrm{~m}$ ). A stretch of shore platforms immediately north of Lorne Beach has the lowest overall exposure along the entire study area. The lowest ranked platform $\left(\mathrm{M}_{\mathrm{e}}=\right.$ -1.94) occurs here and 8 of 13 platforms have an exposure category of between 1 and 3. Of particular interest are the exposure values at Jump Rock, a very popular rock fishing location. In general this section of platform is of low exposure (category 1 and 2) due to the high elevation of the platform, but the position where rock fishing most commonly occurs (Pers Obs) (Fig. 6), ranks as 4 and 5. At the southern end of the Lorne area (around Point Grey) the exposure values are higher mostly between 5 and 7 . The highest $M_{e}$ value is 1.00 where an area of low elevation platform corresponds to a high front depth. At Point Grey the exposure tends to be highest at the tip of the point although one location of low exposure (category 1) occurs on the northern edge of the headland.

South of Apollo Bay there is an equally diverse range of exposures (Fig. 7). Values tend to be high close to Cape Otway with maximum $\mathrm{M}_{\mathrm{e}}$ of 1.28 being recorded where platforms with a low elevation and high front depth are found. In the central part of this area the platforms are generally higher (>1 m above MLWS) and consequently the exposure is less (between category 1 and 4). Like the northern area there appears to be little relation between width and 
$\mathrm{M}_{\mathrm{e}}$ with platforms that extend $>100 \mathrm{~m}$ in the subtidal zone having a similar variation in exposure as those which terminate on a sandy sea floor close to shore immediately below MLWS level.

In some instances the data to calculate FD may not be available or be of too low a resolution. To test whether substituting FD with another value can give a reasonable value of $\mathrm{M}_{\mathrm{e}}$, buffers of 20, 50, 100 and $150 \mathrm{~m}$ were set around each point where elevation was determined. In each buffer the greatest depth was used as a proxy for FD. The relationship between exposure values calculated for buffer-derived and morphologically-derived FD was variable. The smallest buffer has the least correlation between the two measures $\left(r^{2}=0.15\right)$, but as the buffer was increased to $100 \mathrm{~m}$ the correlation improved (Fig. 8). These results indicate that an arbitrary depth offshore can provide an approximation of exposure.

Risk

As risk is a combination of exposure and hazard (Crozier and Glade 2004), wave dynamics should be included in assessments of platform safety. This is because highly exposed platforms in sheltered locations will not be as dangerous as those exposed to high energy waves. To test this relationship a wave model for the Otway Ranges coast (Rattray et al. 2015) was compared to the morphological exposure data. Maximum significant wave height and period ranged from $2.4-4.0 \mathrm{~m}$ and $5.5-7.3 \mathrm{sec}$ respectively. From this data wave orbital velocity $(60 \mathrm{~m}$ grid) is calculated and ranges from $0.40-1.11 \mathrm{~m} / \mathrm{sec}$ with an average of 0.71 $(+/-0.15 \mathrm{~m} / \mathrm{sec})$. There is little correlation between platform exposure and maximum significant wave height $\left(H_{\operatorname{Smax}}\right)\left(\mathrm{r}^{2}=0.00\right)$ or energy $\left(\mathrm{r}^{2}=0.03\right)$ highlighting the independence of morphology and wave energy.

To quantify risk both offshore energy and wave character $\left(H_{S m a x} / T\right)$ were combined with morphological exposure through:

$$
\begin{aligned}
& \text { Risk }=\text { Exposure }\left(\mathrm{M}_{\mathrm{e}}\right) \times \text { Wave Orbital Velocity } \\
& \text { Risk }=\text { Exposure }\left(\mathrm{M}_{\mathrm{e}}\right) \times\left(H_{\text {Smax }} / T\right)
\end{aligned}
$$

Comparing the ranking distribution of sites (Fig. 9) inclusion of wave orbital velocity (equation 4) slightly reduces the overall risk ranking of sites, with the median ranking falling 
from 5 to 4, with an average of 4.52 +/- 0.09 and 4.29 +/- 0.10 for exposure and risk respectively. Maximum significant wave height and period (equation 5) on the other hand led to an increased risk ranking with $15 \%$ of platforms being ranked at the highest risk compared with $12 \%$ for exposure calculation alone or $9 \%$ for orbital velocity determined risk. Spatially the change in ranking associated with orbital velocity calculated risk can be observed north of Lorne, where all sites fell by at least 1 point in response to the low wave energy in the nearshore zone (Fig. 5). Variation is still high between sites with areas of high and low risk being located along the same stretch of coastline.

\section{Discussion}

The analysis of shore platforms along the Otway Ranges of Victoria, Australia highlights the site-specific nature of exposure hazard and risk on rocky shores. Exposure rankings between sites are highly variable even though they may occur on the same section of shore platformdominated shoreline. This variation in risk is fundamentally different to that observed on beaches. For Australian beaches, variability in hazard is most commonly related to the positioning of rips (Short and Hogan 1994). Rips are localised (10 - $100 \mathrm{~m}$ scale) seaward flowing currents whose position is related to interactions between waves of different periods and structures on the beach (Brander 2015). Even though rips themselves are localised features, when beaches are assessed for hazards kilometre-scale beach morphology is used (Short 1999). For example on a $50 \mathrm{~km}$ long stretch of Ninety Mile Beach in Victoria, between The Honeysuckles to Second Blowhole, 14 locations are assessed for hazard and they are all given the same value (6 out of 7). Such uniformity in hazard is in stark contrast to that observed on shore platforms.

The complexity of nearshore seabed morphology is a major reason for the variability in hazard between the two landform systems. While rips and bars do produce metre-scale relief over tens to hundreds of metres in an alongshore direction, when compared to shore platforms the rugosity and alongshore variability are much lower. For example along the Otway coast subtidal morphology can vary by several metres along a section of coast $<10 \mathrm{~m}$ long. This can occur when platforms adjacent to each other transition between a cliff, ramp or reef morphology (Kennedy 2016). The complexity of nearshore bathymetry is noted as a major influence on wave overtopping of artificial structures such as seawalls (e.g. Allsop et al. 2005; Gallien et al. 2014) and modelling of such processes is very complex (e.g. Gotoh et 
al. 2005; Losada et al. 2008). Therefore as nearshore morphology becomes more complex so does the transformation of wave energy at the shoreline and subsequently the likelihood of wave overtopping.

Drowning hazards can be site specific, and can be associated with deep holes, gulches, or channels on platforms. In the study area, channels several metres deep are often cut through the platforms along bedding and joint planes (Jutson 1949; 1953). These channels allow energy to propagate onto the platforms and therefore create a higher risk to people. Although the hazard of these small-scale features was not explicitly tested in this study, they can be included in the exposure index as the channel depth can be parameterised through a higher front depth.

An additional consideration for rock safety is the ability of a person to exit the water after they have fallen off a platform. Less than half metre changes in the height of ledges in swimming pools have been noted to significantly affect the ability of a person to climb out of the water (Moran 2014). For rocky coasts the seaward edge of the platform may in fact be so high as to preclude any attempt to climb out. In fact, in instances where the platform edge may be undercut such as commonly occurs on limestone platforms (Semeniuk and Johnson 1985) people are known to have been trapped under the platform edge (Life Saving Victoria, Pers. Comm., 2015). Such aspects of 'the exiting problem' are not a focus of the exposure index, but do highlight the complex role that morphology plays in determining risk on the rocky shore.

The behaviour of people on a platform is another confounding factor in estimating risk. People's method of accidently entering the water is commonly not related to a specific wave event, but rather is a function of slipping and subsequently falling into the ocean (Kamstra, 2015). People also intentionally stand on the very edge of the platform in order to obtain an artistic photograph or 'selfie' oblivious to the approaching waves (Pers. Obs.). Such behaviour can be independent of the prevailing wave conditions, but in some instances observed during this research, people deliberately place themselves at higher risk as a thrill seeking activity. Understanding the human behaviour on the rocky shore is a necessary next step in a holistic understanding of shore platform hazard. 
The critical aspect for the calculation of exposure and risk is precisely where elevation and FD are calculated. In this study we analysed the platforms under low tide conditions; however, the complexity of the seaward edge would likely mean exposure differs when tides are high. In addition, people stand on platforms at different elevations. The movement of people along the edge of the platform therefore constantly places them in different exposure scenarios. Such activities can however be accounted for by selecting a variety of positions on the platform when assessing exposure. If a single exposure value is to be calculated then the Precautionary Principle (Kriebel et al. 2001) would suggest the most exposed, and thus the most seaward, site be quantified.

The main limitation to the calculation of exposure and risk is data availability. In this study the data quality was excellent but this is often not the case. In such instances a set depth offshore of the platform may suffice for the quantification of front depth. In our preliminary test $100 \mathrm{~m}$ produced the most robust correlation. More detailed work on wave dynamics on the shore platforms edge is needed to precisely quantify where wave dissipation principally occurs and how it is best quantified on the platform edge.

\section{Conclusions}

The exposure of visitors on microtidal shore platforms is a product of the depth offshore of the platform (front depth) and the elevation of that part of the rocky coast. Platforms at lower elevations and with greater front depths are most exposed to waves. The complexity of nearshore morphology means that exposure is highly variable along small (100 $\mathrm{m}$ scale) sections of coastline. This is the result of variations in the orientation and structure of the geology inwhich the platforms are formed. The variation in exposure to waves can be represented in the morphological exposure index developed in this paper.

The advantage of the index is that it can be calculated based on two simple landform elements, front depth and elevation. The index is a relative measure of the potential exposure to wave overtopping, but does not account for other environmental hazards such as slipping. This provides managers with a tool to assess the likely wave exposure of any particular section of microtidal coast. Detailed hydrodynamic modelling is needed to fully understand danger; however, its calculation is very difficult in highly complex morphological settings such as rock coasts. The advantage of the index developed here is that when detailed inshore wave data is available exposure can be converted into an actual risk index. In this study risk 
and exposure for sites which are less dangerous appears to be quite similar; however, larger variations occur at medium to highly ranked sites.

\section{Acknowledgements}

This project is funded by the Australian Research Council Linkage Program (LP130100204). We thank the Department of Environment and Primary Industries coordinated imagery program for access to the georegistered aerial photography and the Future Coasts Program for access to the LiDAR data. Comments on a draft of the manuscript by Colin Woodroffe and Gigi Woods were greatly appreciated as were reviews by Alan Trenhaile and an anonymous expert. 


\section{Figure Captions}

Figure 1: The location of the Otway coast of Victoria, Australia. This is one of the most popular holiday destinations in the state.

Figure 2: The characteristic shore platform morphologies found along the Otway coast and the position used to calculate elevation $\left(\mathrm{SP}_{\mathrm{e}}\right)$ and front depth (FD). Three different types of platform edge are found, (a) steep seaward cliff, (b) a ramp and (c) a subtidal reef/terrace.

Figure 3: Frequency histograms of (a) platform elevation and (b) front depth along the Otway Coast relative to mean low water spring elevation (MLWS). (c) The complexity of platform morphology is represented in the almost random relation between elevation and front depth.

Figure 4: (a) The relationship between exposure and elevation when multiplying the parameters. There is a trend towards an exposure of zero at the elevation which the data is normalised too. (b) An exponential trend towards infinity in exposure values when dividing the parameters. When a $\log _{10}$ transformation is used the exposure values are not as sensitive to slight changes close in values close to MLWS for both (c) elevation and (d) front depth.

Figure 5: Exposure and orbital velocity-based risk values for the northern section of the study area near the township of Lorne.

Figure 6: People rock fishing at (a) Jump Rock, Lorne and (b) Artillery Rocks, 8 km south west of Lorne.

Figure 7: $\quad$ Exposure and orbital velocity-based risk values for the southern section of the study area from Apollo Bay to Cape Otway.

Figure 8: Calculating the front depth based on a set buffer around the platform edge results in a varying estimation of exposure. The correlation with morphology-based exposure values is greatest with the $100 \mathrm{~m}$ buffer. Platforms within centimetres of MLWS $(n=4)$ were excluded in this analysis.

Figure 9: (a) There is a strong relationship between risk and exposure for all the sites analysed, however (b) the overall ranking of the sites is variable when energy data is included when calculating risk. 


\section{Supplementary Electronic Information}

The supplemental GoogleEarth file shows the full dataset used in the calculation of exposure.

The values refer to the calculated exposure for a site to any wave approaching the shore. They therefore require the addition of detailed inshore energy data to calculate hazard. The location of each point is the assumed position of a person used in each calculation. The scale is the same as in Figures 5 and 7. 


\section{References}

Allsop W, Bruce T, Pearson J, Besley P (2005) Wave overtopping at vertical and steep seawalls Maritime Engineering 158:103 - 114

Beetham EP, Kench PS (2011) Field observations of infragravity waves and their behaviour on rock shore platforms Earth Surface Processes and Landforms 36:1872 - 1888

BoM (2015) Climate and Past Weather. Australian Government, http://www.bom.gov.au/climate/

-Brander RW (2015) Rip currents. In Ellis JT, Sherman DJ (eds) Coastal and marine hazards, risks and disasters, Elsevier, pp 335 - 380

Crozier MJ, Glade T (2004) Landslide hazard and risk: Issues, concepts and approach. In: Glade T, Anderson M, Crozier MJ (eds) Landslide Hazard and Risk. John Wiley and Sons, pp 1 - 40

DHI (2012) Mike 21 spectral wave module, Scientific Documentation. Danish Hydraulic Institute (DHI).

Douglas JG, Ferguson JA (eds) (1976) Geology of Victoria vol Special Publication \#5. Geological Society of Australia,

Duddy IR (2003) Mesozoic. In: Birch WD (ed) Geology of Victoria, vol Geological Society of Australia Special Publication 23. Geological Society of Australia (Victoria Division), Sydney, pp 239 - 288

Gallien TW, Sanders BF, Flick RE (2014) Urban coastal flood prediction: Integrating wave overtopping, flood defenses and drainage Coastal Engineering 91:18-28

Gill ED (1973) Rate and mode of retrogradation on rocky coasts in Victoria, and their relationship to sea level changes Boreas 2:143 - 171

Gotoh H, Ikari H, Memita T, Sakai T (2005) Lagranguan particle method for simulation of wave overtopping on a vertical seawall Coastal Engineering Journal 47:157-181

Hughes MG, Heap AD (2010) National-scale wave energy resource assessment for Australia Renewable Energy 35:1783 - 1791

Jutson JT (1949) The shore platforms of Lorne, Victoria Proceedings of the Royal Society of Victoria 61:43 - 59

Jutson JT (1953) The shore platforms of Lorne, Victoria, and the processes of erosion operating thereon Proceedings of the Royal Society of Victoria 65:125 - 134

Kamstra P (2015) Relational risk on microtidal shore platforms and implications for public safety on rocky coasts. Master of Science thesis, The University of Melbourne. 
Kennedy DM (2016) The subtidal morphology of microtidal shore platforms and its implication for wave dynamics on rocky coasts. Geomorphology 268:146 - 158.

Kennedy DM, Brighton B, Weir A, Sherker S, Woodroffe CD (2012) Towards a typology of rocky coasts in the context of risk assessment. Paper presented at the 21 st NSW Coastal Conference, Kiama.

Kennedy DM, Milkins J (2015) The formation of beaches on shore platforms in microtidal environments Earth Surface Processes and Landforms 30:34 - 36

Kennedy DM, Paulik R, Dickson ME (2011) Subaerial weathering versus wave processes in shore platform development: reappraising the Old Hat Island evidence Earth Surface Processes and Landforms 36:686 - 694

Kennedy DM, Sherker S, Brighton B, Weir A, Woodroffe CD (2013) Rocky coast hazards and public safety: moving beyond the beach in coastal risk management Ocean and Coastal Management 82:85 - 94

Kriebel D et al. (2001) The precautionary principle in environmental science Environmental Health Perspectives 109:871-876

Losada IJ, Lara JL, Guanche R, Gonzalez-Ondina JM (2008) Numerical analysis of wave overtopping of rubble mound breakwaters Coastal Engineering 55:47-62

Moran K (2014) Getting Out of the Water: How Hard Can That Be? International Journal of Aquatic Research and Education 8:321 - 337

Ogawa H, Dickson ME, Kench PS (2015) Hydrodynamic constraints and storm wave characteristics on a sub-horizontal shore platform Earth Surface Processes and Landforms 40:65 - 77

PoM (2013) Victorian Tide Tables, 88th edn. Port of Melbourne Corporation, Melbourne

Quadros N, Rigby J (2010) Construction of a high accuracy seamless, state-wide coastal DEM. FIG Coastal Zone Special Publication, Sydney

Rattray A, Ierodiaconou D, Womersley T (2015) Wave exposure as a predictor of benthic habitat distribution on high energy temperate reefs Frontiers in Marine Science 2 doi:10.3389/fmars.2015.00008

Semeniuk V, Johnson DP (1985) Modern and Pleistocene rocky shore sequences along carbonate coastlines, southwestern Australia Sedimentary Geology 44:225-261

Short A (1999) Beach hazards and safety. In: Short A (ed) Handbook of beach and shoreface morphodynamics. John Wiley \& Sons, pp 293 - 304

Short A, Hogan CL (1994) Rip currents and beach hazards: their impact on public safety and implications for coastal management Journal of Coastal Research SI12:197 - 209 
Short A, Williamson B, Hogan CL (1993) The Australian beach safety and management programme - Surf Life Saving Australia's approach to beach safety and coastal planning. In: 11th Australasian conference on coastal and ocean engineering, Barton, ACT. Institution of Engineers, Australia, pp 113 - 118

SLSA (2014a) Annual Report 2013/14 Surf Life Saving Australia, Sydney

SLSA (2014b) National Coastal Safety Report 2014. Surf Life Saving Australia, Sydney

Stephenson WJ, Dickson ME, Trenhaile AS (2013) 10.11 Rock Coasts. In: Editor-in-Chief:

John FS (ed) Treatise on Geomorphology. Academic Press, San Diego, pp 289-307.

Sunamura T (1992) Geomorphology of rocky coasts. John Wiley \& Sons, Chichester

Trenhaile AS (1987) The geomorphology of rock coasts. Clarendon Press, Oxford.

WaterTech (2004) Wave and tidal power assessment for the Victorian coastline. Notting Hill, Victoria

Whiteway T (2009) Australian Bathymetry and Topography Grid, June 2009. Scale 1:5000000. Geoscience Australia, Canberra

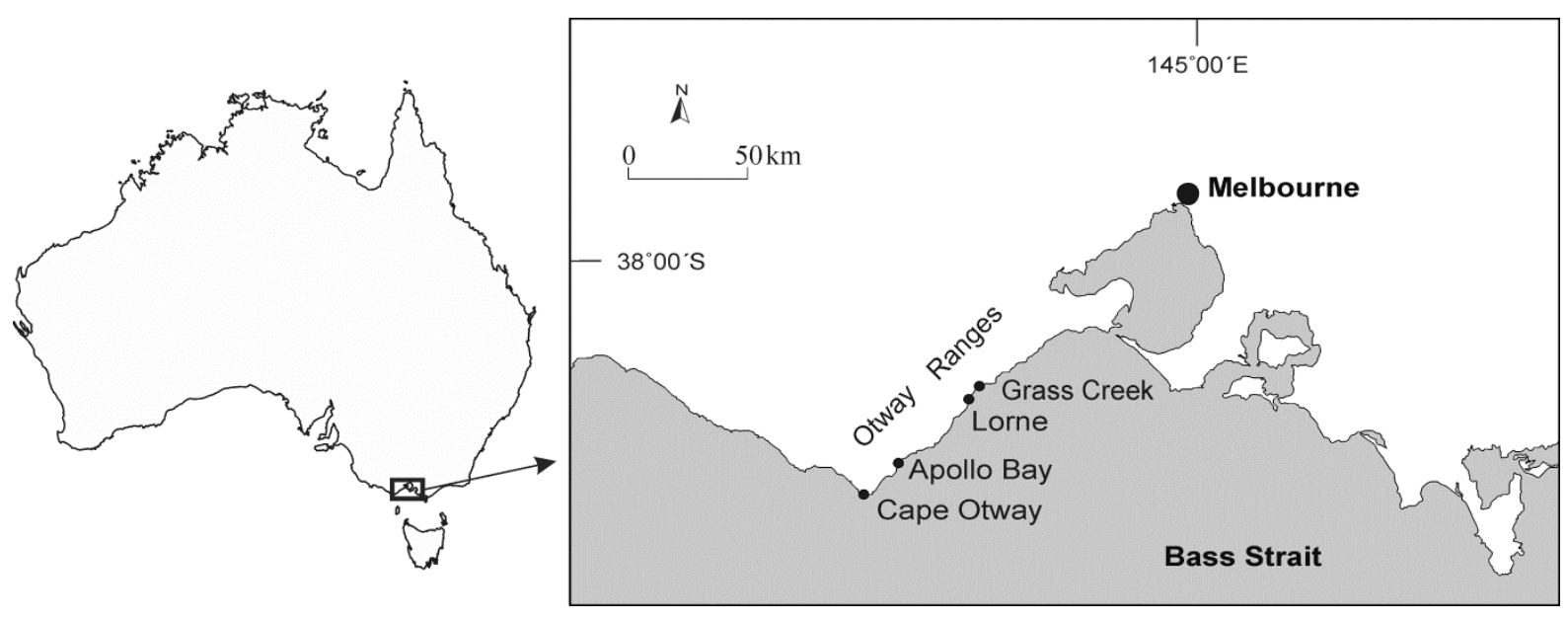


(a)

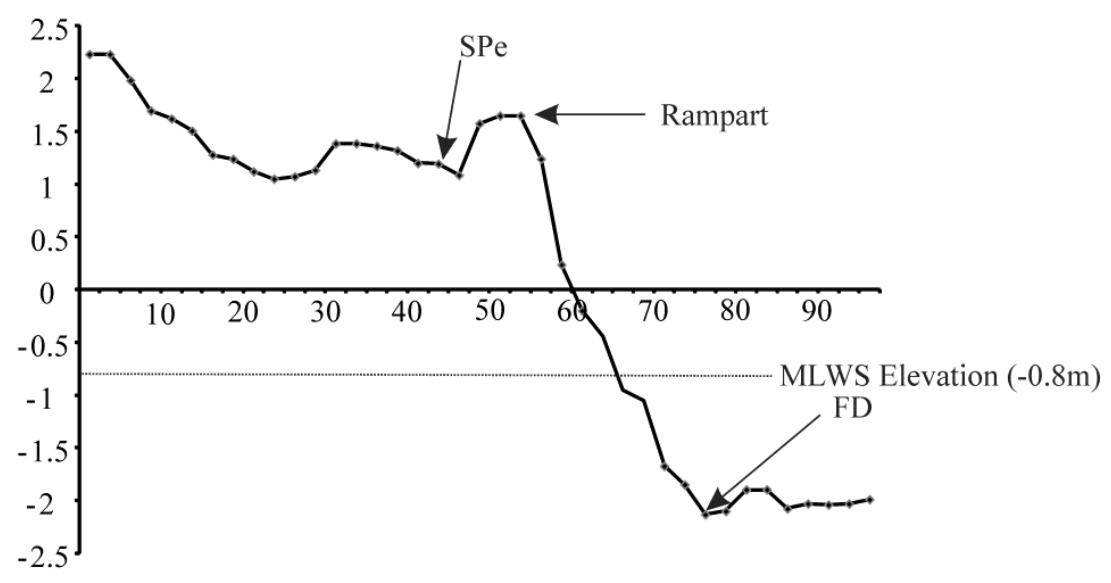

(b)

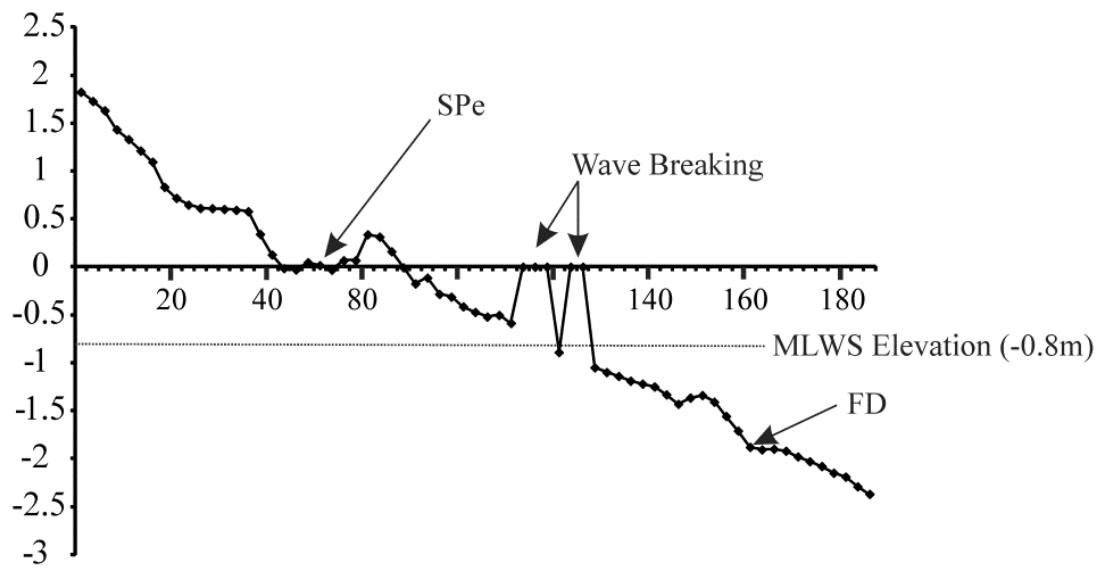

(c)

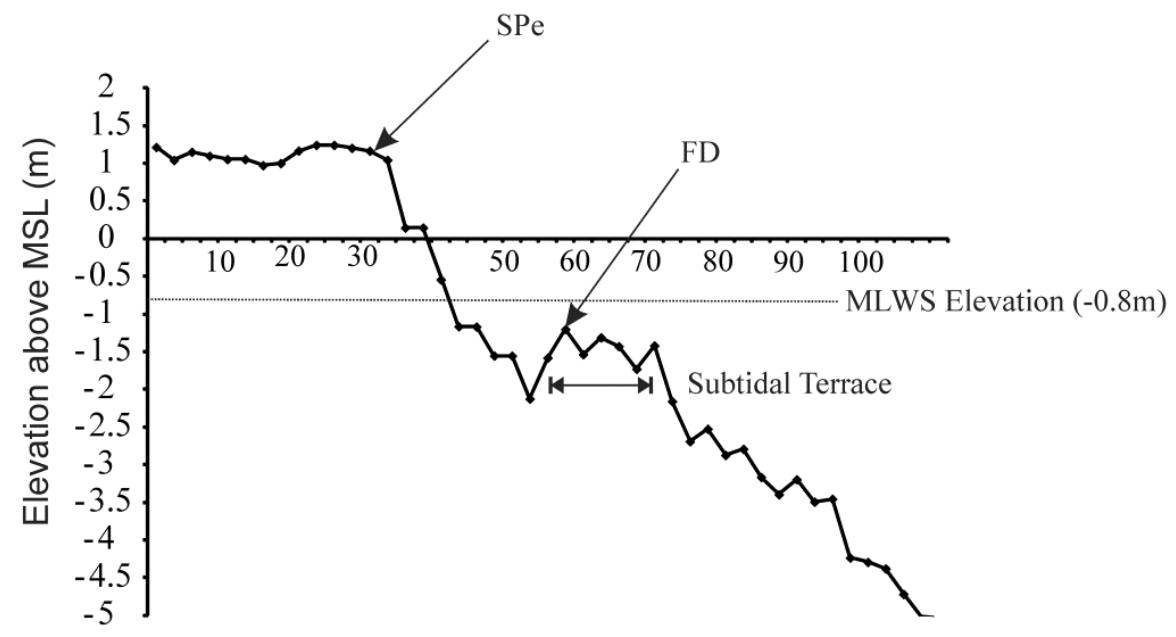




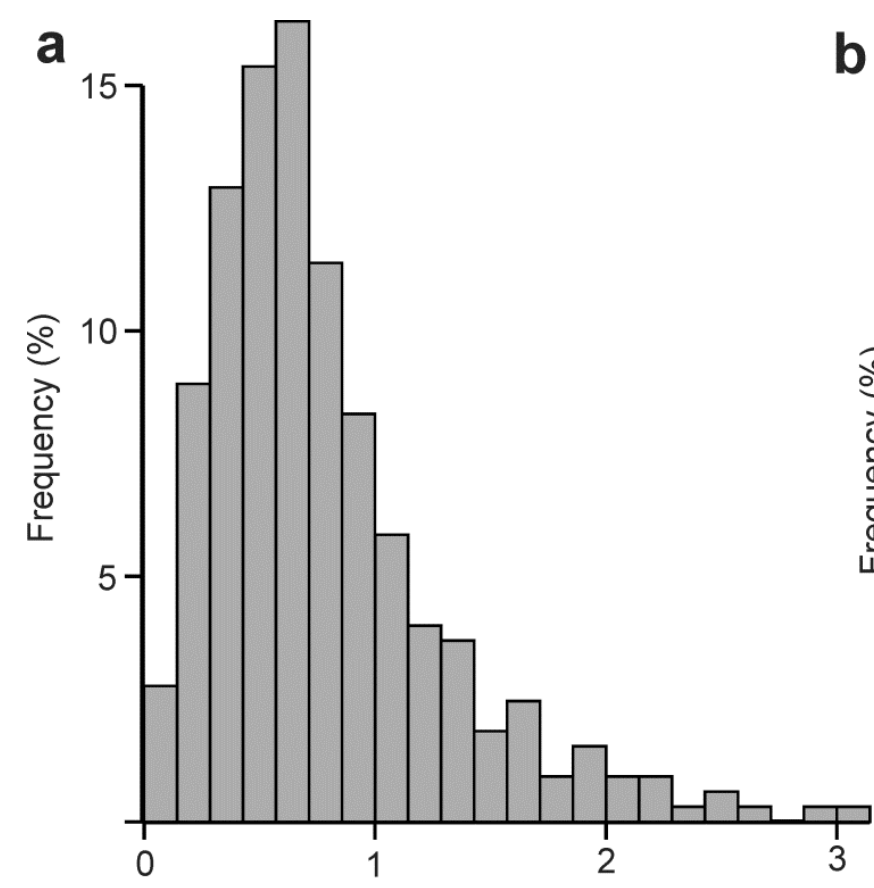

Height above MLWS (m)

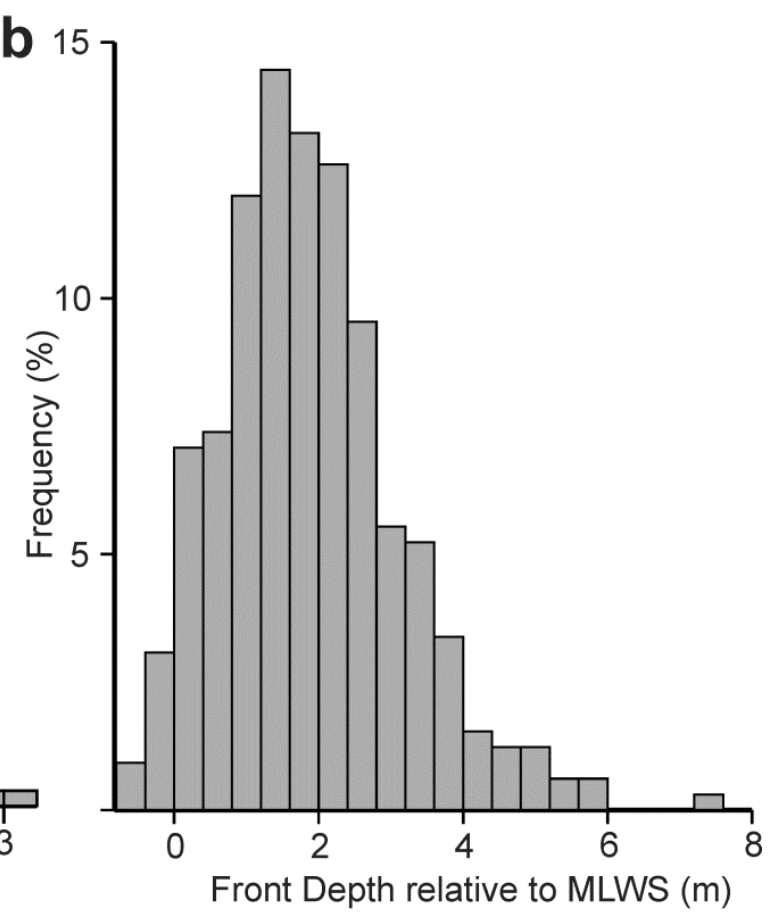

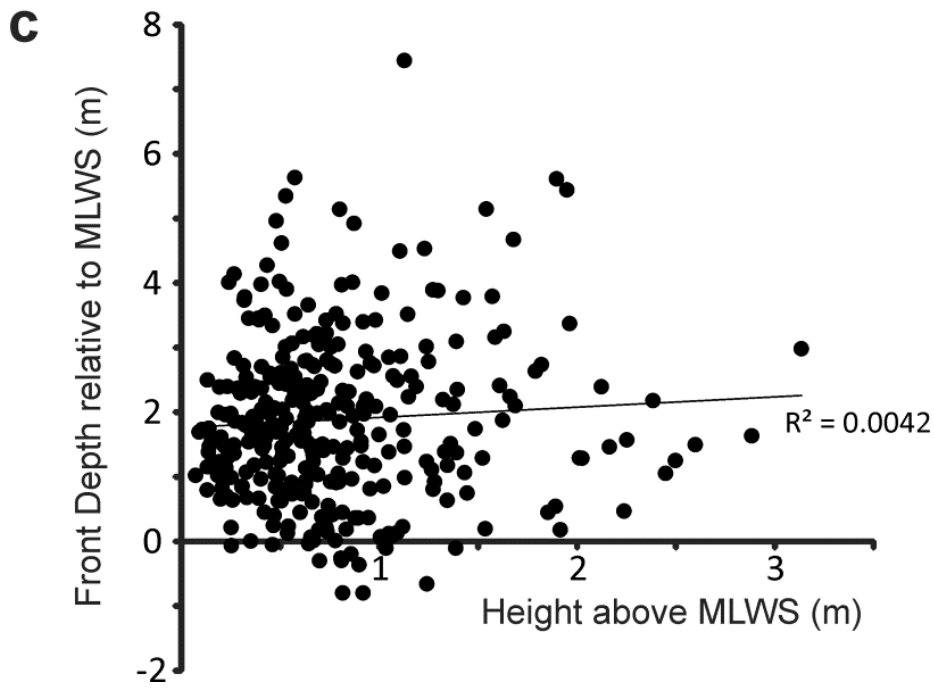



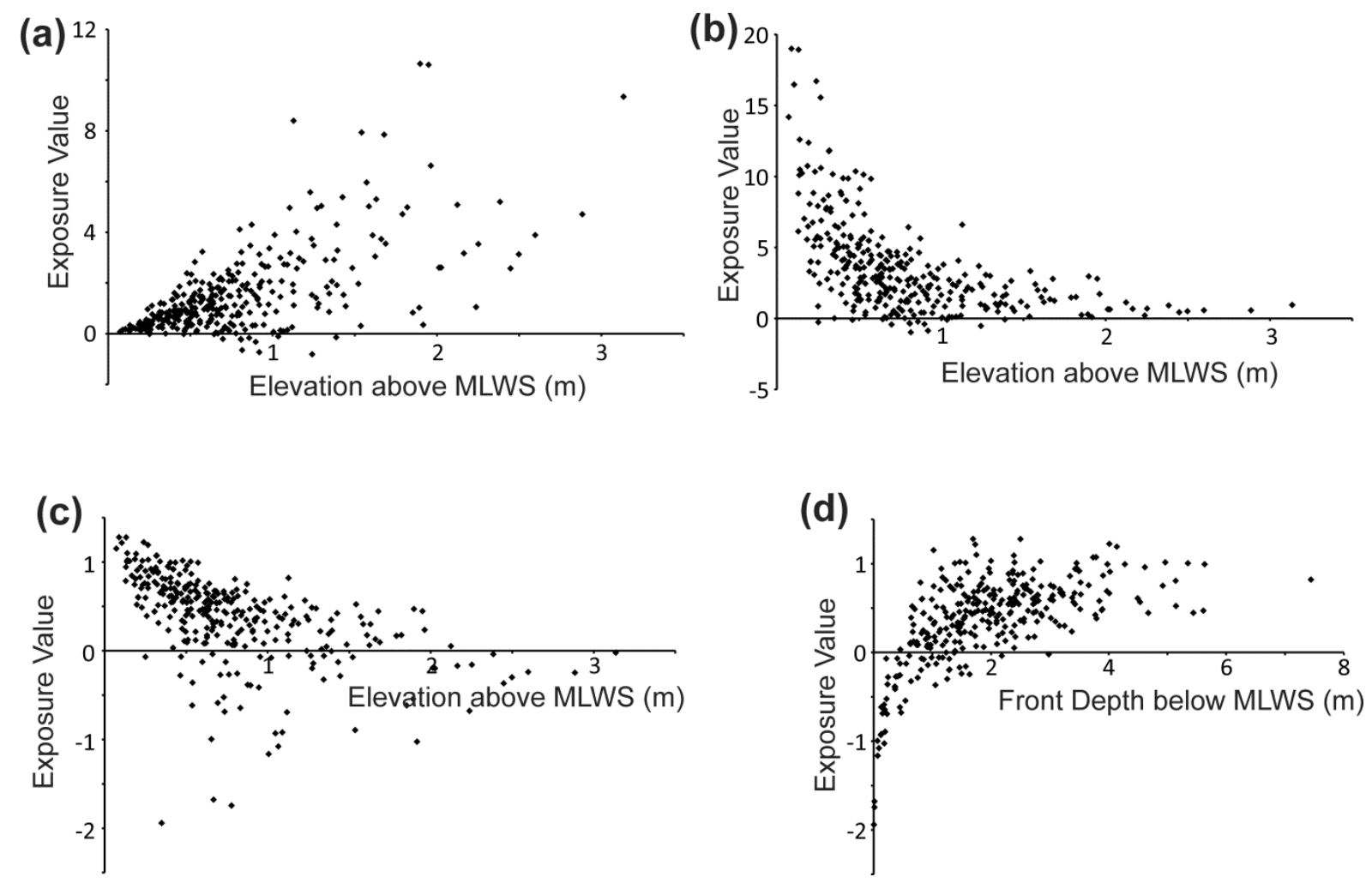


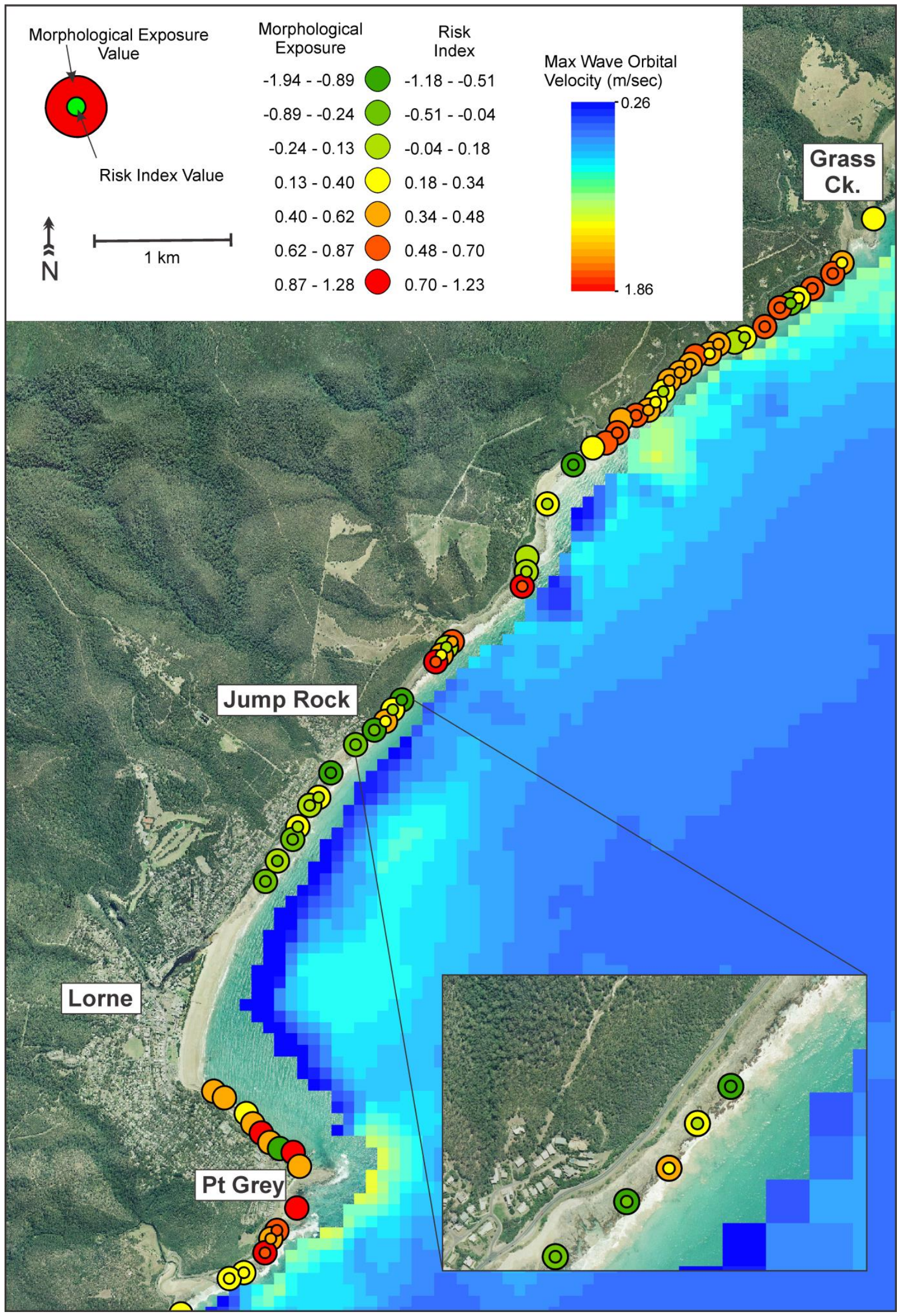




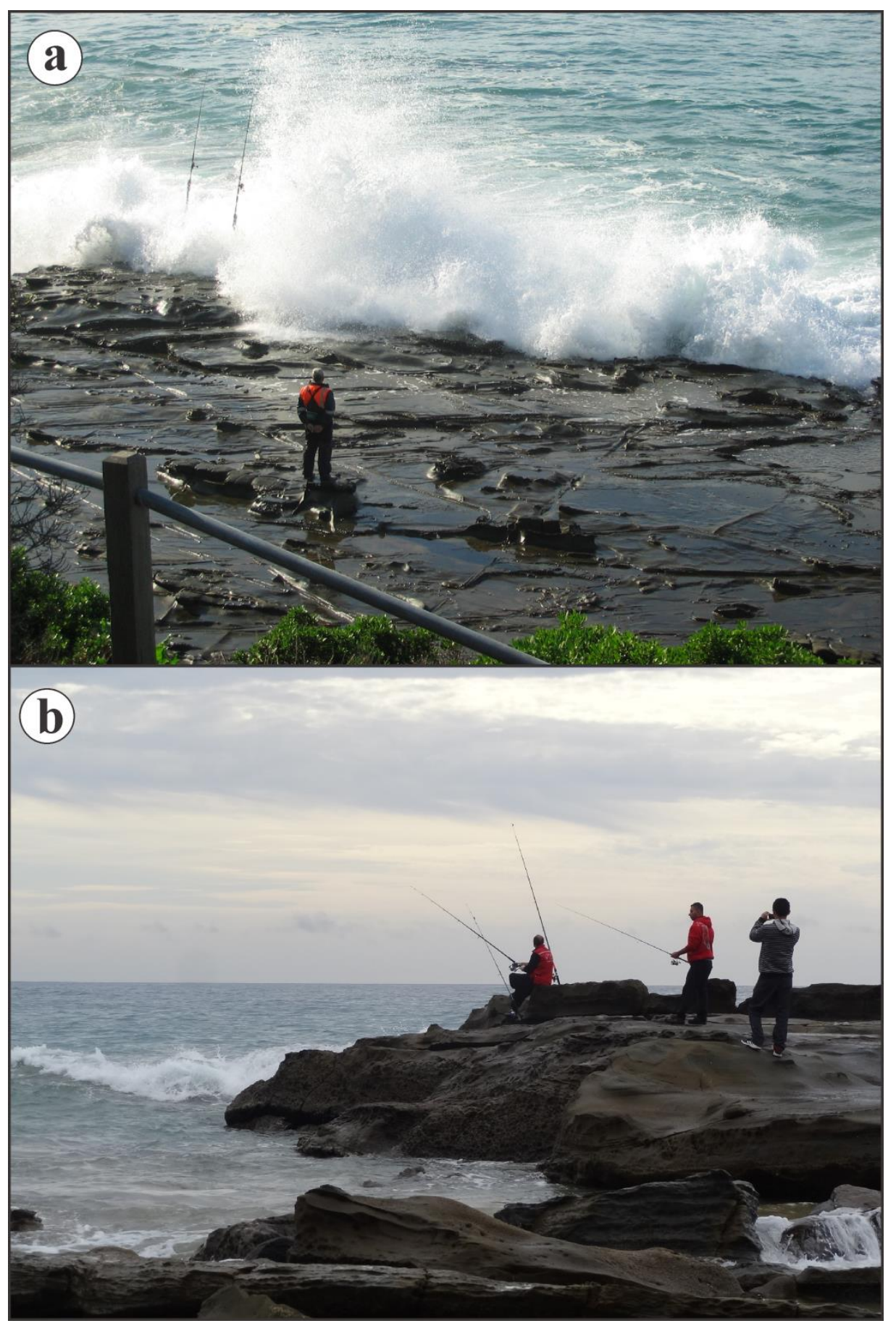



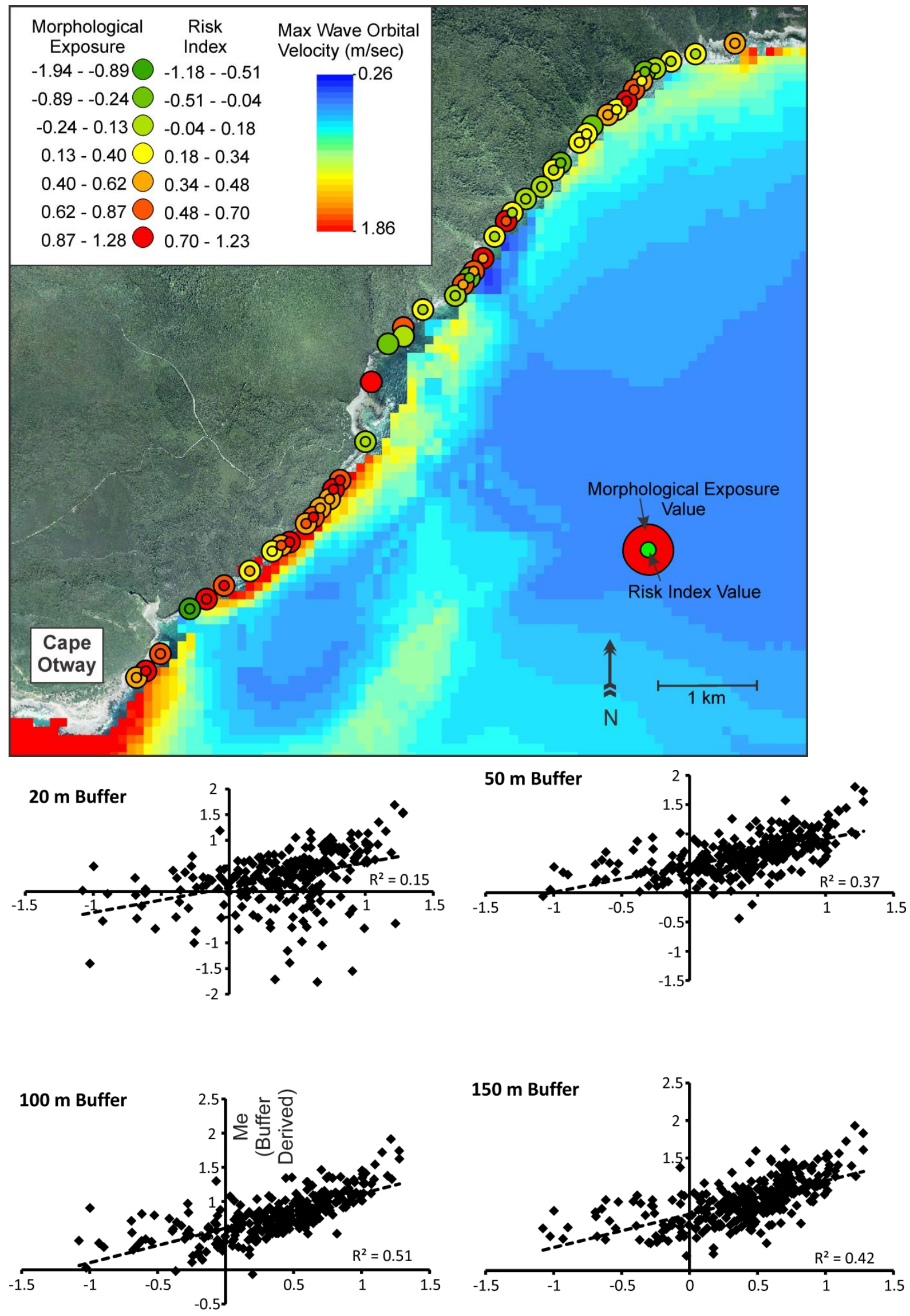

Me (Morphology Derived) 


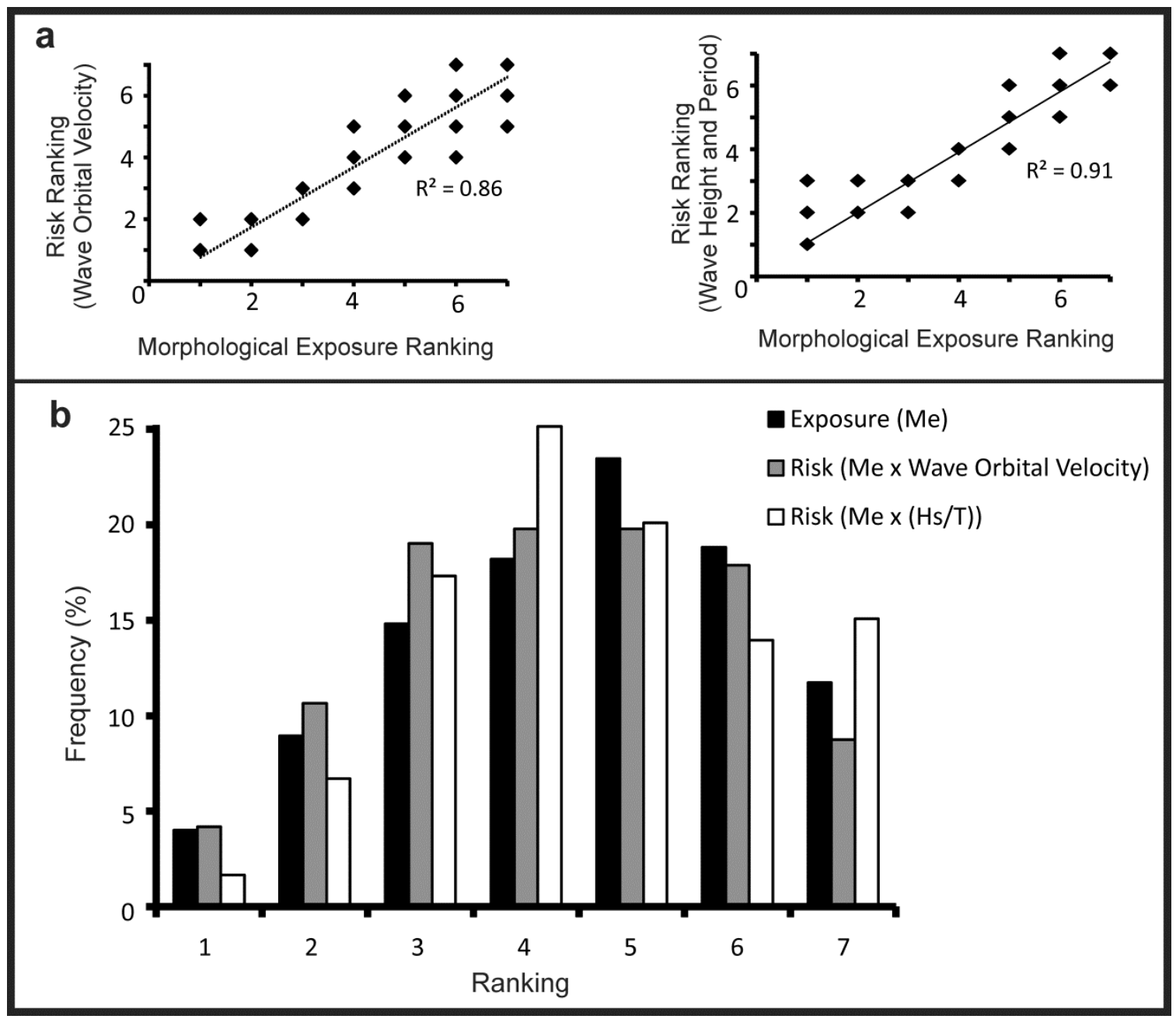




\section{University Library}

\section{- M M I N E R VA A gateway to Melbourne's research publications}

Minerva Access is the Institutional Repository of The University of Melbourne

Author/s:

Kennedy, DM; Ierodiaconou, D;Weir, A;Brighton, B

Title:

Wave hazards on microtidal shore platforms: testing the relationship between morphology and exposure

Date:

2017-03-01

\section{Citation:}

Kennedy, D. M., lerodiaconou, D., Weir, A. \& Brighton, B. (2017). Wave hazards on microtidal shore platforms: testing the relationship between morphology and exposure. NATURAL HAZARDS, 86 (2), pp.741-755. https://doi.org/10.1007/s11069-016-2714-1.

Persistent Link:

http://hdl.handle.net/11343/282541 